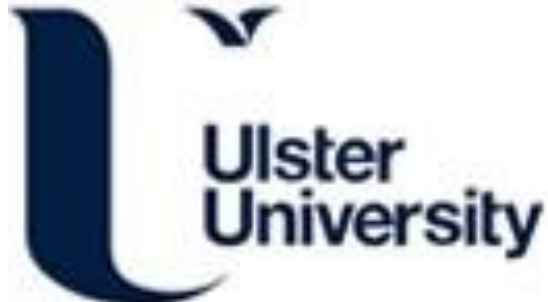

\section{Politics, resistance and patronage: the African boycott of the 1966 World Cup and its ramifications}

Darby, P. (2019). Politics, resistance and patronage: the African boycott of the 1966 World Cup and its ramifications. Soccer and Society, 20(7-8), 936-947. https://doi.org/10.1080/14660970.2019.1680494

Link to publication record in Ulster University Research Portal

Published in:

Soccer and Society

Publication Status:

Published (in print/issue): 20/10/2019

DOI:

https://doi.org/10.1080/14660970.2019.1680494

\section{Document Version}

Author Accepted version

\section{General rights}

Copyright for the publications made accessible via Ulster University's Research Portal is retained by the author(s) and / or other copyright owners and it is a condition of accessing these publications that users recognise and abide by the legal requirements associated with these rights.

\section{Take down policy}

The Research Portal is Ulster University's institutional repository that provides access to Ulster's research outputs. Every effort has been made to ensure that content in the Research Portal does not infringe any person's rights, or applicable UK laws. If you discover content in the Research Portal that you believe breaches copyright or violates any law, please contact pure-support@ulster.ac.uk. 
Politics, Resistance and Patronage: The African Boycott of the 1966 World Cup and its Ramifications

Dr Paul Darby

School of Sport

Ulster University

Shore Road

Newtownabbey, BT37 0ZH

N. Ireland

T: 02890366416

E: p.darby@ulster.ac.uk 


\title{
Politics, Resistance and Patronage: The African Boycott of the 1966 World Cup and its Ramifications
}

\begin{abstract}
The 1966 World Cup Finals are remembered primarily for on-field events, not least the host's capture of the Jules Rimet trophy, the performances of the minnows of North Korea in reaching the quarter-finals and the Eusebio inspired exploits of the tournament's other debutants, Portugal. What is less prominent in this history but more significant in impacting the longer-term trajectory of the World Cup and the global game, are events off the field of play, specifically the decision of African nations to boycott the qualifying rounds of the tournament. This paper assesses the circumstances behind this boycott, both within FIFA and in the highly charged political climate that characterized the immediate post-colonial era. Particular attention is paid to the role of Ghana as the boycott's chief architect. Thereafter, I explore some of the intended and unintended consequences of the boycott, including its contribution to an ongoing transformation in the global governance of football.
\end{abstract}

Key Words: Ghana; Boycott; Kwame Nkrumah; World Cup; Confédération Africaine de Football (CAF); Fédération International de Football Association (FIFA)

\section{Introduction}

In the context of FIFA World Cup history, 1966 is remembered primarily for events on the field of play, not least the host's capture of the Jules Rimet trophy, the performances of the minnow's of North Korea in reaching the quarter-finals and the Eusebio-inspired exploits of the tournament's other debutants from Portugal. What is less prominent in this history but I would argue more significant in impacting the longer-term trajectory of the World Cup and the global game more generally, are events off the field of play, specifically the decision of African nations to boycott the qualifying rounds for the 1966 tournament in protest against what was considered by the Confédération Africaine de Football (CAF) as an 'outrageously unfair' distribution of places for the World Cup Finals. ${ }^{1}$ Drawing on official minutes, personal correspondence from key protagonists and newspaper reportage mined over a fifteen year period from archives in Cairo, Accra, Zurich, New York and the UK, this study examines the circumstances that gave rise to this boycott and explores some of its key consequences, intended and unintended. 
The article begins by briefly accounting for the significance of three interrelated processes that underpinned Africa's emerging role in the world game in the late colonial and early post-colonial period and that fed into the boycott. The first relates to the growing politicisation of African football and its role as a locus for anti-colonial, embryonic nationalist sentiment. The second was African football's collective response to a deeply infused and long-standing Eurocentrism within the Fédération International de Football Association (FIFA). Finally, and the one that most directly underscored the boycott, was the aspiration of newly independent African nations to use the world game, and in particular, the World Cup, as a vehicle for registering their presence and acquiring recognition on the international stage. Given that these processes were particularly pervasive in Ghana and that much of the impetus for the boycott strategy came from this country, specific attention is accorded to its role as the chief architect. More specifically, the article unpacks how the rationale behind the boycott reflected the pan-African vision of Kwame Nkrumah, Ghana's first President. In doing so, this paper reveals how football, and the boycott articulated with wider political currents of the time. Thereafter, attention shifts to exploring some of the intended and unintended consequences of the boycott, including how it contributed to an unparalleled transformation in the global governance of football.

\section{Football, Eurocentrism and resistance in the late colonial and early post-colonial period}

Prior to the independence movements that swept the African continent in the late 1950s and early 1960s, FIFA operated primarily in the interests of the game's established European and South American constituencies. ${ }^{2}$ In this context, Africa was considered largely as an irrelevance, not least because with Ethiopia's affiliation to FIFA in 1953 the number of African members within FIFA totalled just four. While the inception of CAF in 1957 created 
a platform on which to push for the more internationalist agenda that FIFA claimed was at the heart of its mission, ${ }^{3}$ the Africanisation of the game and its growing status as a site for anticolonial sentiment and the articulation of nascent nationalism in the post-war period was equally as important in the decision to employ a highly politicised boycott strategy to protest against FIFA's European bias. It is not necessary here to detail the role of the game in this regard, except to say that there is a small, but important historiography on the political pedigree of football in colonial Africa, specifically in North Africa, the Belgian Congo, Tanzania, Zanzibar, Ghana, Nigeria and Algeria. ${ }^{4}$ In his survey of the relationship between football, nationhood and the movement for independence in late colonial Africa, Ossie Stuart summarised the central argument of this historiography by pointing to the fact that the game became 'an embodiment of the political aspirations of the African people' and was used across the continent as an 'expression of defiance towards the state and of independence from their colonial oppressors'. ${ }^{5}$

Football's role as a conduit for fledgling senses of nationhood and growing anticolonial mobilisation infused the game with a collectivist and at times, radical political pedigree. This rendered it a utilitarian vehicle both for post-independence nation building and for pursuing recognition in the post-colonial world. While football in this period continued to nourish more parochial ethnic identities in Africa, ${ }^{6}$ the establishment of national leagues and investment in national teams were identified as important in mobilising youth around a common sense of national identity. However, the strategic use of the game by newly independent nations to register and project their presence on the international stage was predicated on access to and opportunities in international football. While FIFA's statutes did not prevent these countries from affiliating to the world body, a deeply entrenched Eurocentrism, one that became more prevalent with the expansion in FIFA's constituency 
list, constrained African nations' pursuit of the visibility and recognition that they felt the world game should offer.

Despite being small in number prior to the late 1950s, FIFA's African membership had articulated a desire for better representation in the game's corridors of power and they were eager to establish a confederation to oversee the development of the game across the continent. However, their ambitions were initially frustrated by condescending and patronising attitudes on the part of FIFA's European leadership. ${ }^{7}$ Nonetheless, the initiation of CAF in 1956 and its formal ratification by FIFA the following year, provided a potent dais upon which to respond to this bias. ${ }^{8}$ At the same time that they joined the continental body, football federations from newly independent African states applied for affiliation to the world body. However, FIFA membership meant little unless it was combined with meaningful participation and for an ambitious and expanding African constituency, this meant opportunities to play in the game's most prestigious international competition.

By the early 1960s FIFA's African membership, then numbering more than 20 national associations, began to seek ways of ensuring that the international game's institutional and competition structures developed in ways that accommodated their needs and aspirations. Given that FIFA's electoral franchise at Congress operated on the principle of one nation one vote, it might have been expected that CAF would be in a position to challenge the power imbalances that lay at the heart of the International Federation. However, European administrators, anxious to maintain hegemony within FIFA, had organised themselves into a politically unified confederation in 1954 and they resolved to consolidate their position within FIFA whilst at the same time marginalizing Africa and Asia. ${ }^{9}$ For example, in 1956 Gustav Weiderkehr, later to become President of UEFA, warned of the 'danger' of FIFA's European members finding themselves as an electoral minority unable to veto alterations to FIFA's statutes. ${ }^{10}$ In these circumstances, UEFA made several attempts 
during the late 1950 s and early 1960 s to introduce a pluralist voting system that would more adequately reflect their self-perceived standing in world football. ${ }^{11}$

The failure of these efforts persuaded them to seek to maintain their hegemony in other ways. Chief amongst these was a strategy aimed at ensuring that the format of the World Cup Finals continued to protect European interests at the expense of FIFA's newer members. The World Cup had up until that point reflected Europe's and South America's longer standing international pedigree. For example at the three World Cups between 1954 and 1962, all but two of the sixteen qualifying berths went to teams from these confederations with Europe securing 12 places for 1954 and 1958 and 10 for the 1962 tournament. Despite growing calls for a more representative competition, one that provided meaningful opportunities for the game's emerging members to qualify for, FIFA remained intransigent. Neither Africa nor Asia were granted an automatic qualifying berth and in the early 1960s UEFA's Executive Committee considered, albeit later abandoned, the idea of pushing for a reduction in the number of participants in the Finals as a method of consolidating its position and limiting opportunities for the developing world. ${ }^{12}$ This exclusion was institutionalised in the early 1960s, when as part of qualification for the 1962 tournament in Chile, the world body stipulated that the winners of the African preliminary round (Morocco) would be required to play a further qualifying match against a European team (Spain). ${ }^{13}$ FIFA's refusal to grant Africa its own World Cup berth was formalised in 1964 when the world body introduced a rule requiring the winners of the African zone to play the winners of the Asia/Oceania zone to qualify for future World Cup Finals. This decision was the final provocation and ultimately instigated a more radical approach from Africa, one that was in keeping with the growing confidence of post-colonial African states. 


\section{Football, Nationalism and Pan-Africanism in Kwame Nkrumah's Ghana}

The idea of a continent wide boycott of the qualifying rounds of the 1966 World Cup was initiated and orchestrated by the leading Ghanaian nationalist and ardent pan-Africanist Kwame Nkrumah. Nkrumah's political apprenticeship was embedded in pan-Africanism, a political and intellectual movement that he would go on to lead. While it had roots stretching back to the mid-nineteenth century in the United States, W.E.B. Du Bois was the father of modern pan-Africanism and his promotion of African history and culture inspired subsequent African-American and West Indian intellectuals and activists, including Marcus Garvey, C.L.R. James and George Padmore whose writings and activism did much to build a strong sense of black African consciousness. All were hugely influential in the development of the pan-African Congress movement and the four congresses held between 1900 and 1927 were important in solidifying pan-African ideals into a formal political movement, one that advocated the liberation of African peoples across the diaspora and on the African continent. By the mid-1940s African leaders such as Jomo Kenyatta and Léopold Senghor had become more influential in promoting the pan-African agenda and when the fifth pan-African Congress was convened in Manchester in 1945, Nkrumah, who had moved to London earlier that year to study, was introduced to the increasingly formalised and co-ordinated movement for African liberation. ${ }^{14}$

Nkrumah's route to the forefront of this movement was swift and his contribution to the development of the ideology that underpinned it immeasurable. Shortly before he was invited back to Ghana to begin his journey in the Ghanaian political scene and to push for independence, he had joined a group of fellow committed students in The Circle which was comprised of only the most ardent supporters of Pan-Africanism. ${ }^{15}$ On his return to Ghana in 1947 to take up the position as general secretary of the pro-independence, nationalist political 
party, the United Gold Coast Convention (UGCC), what he had learned from Du Bois, Padmore and other pan-African intellectuals and from his experiences at the Manchester Congress and as a member of The Circle, were woven into his campaign for Ghanaian independence. Once this had been secured, he championed African liberation and unity as the bedrock upon which African interests on the world stage could be best promoted and protected. His convening of a number of conferences in 1958 to build support for and promote these aspirations, and his leading role in the establishment of the Organisation of African Unity in 1963 were evidence of his commitment to pan-African ideals. ${ }^{16}$

In light of his leading role in pan-Africanism, it is hardly surprising that Nkrumah was a central figure in the politicised response to FIFA's allocation of places for the World Cup. Following his return to Ghana, he was quickly persuaded of the value of football as a tool to build popular support for his nationalist and Pan-African aspirations, particularly among young, urban working class men. A keen observer of nationalist currents elsewhere on the continent, Nkrumah could not have failed but to have recognised the politicisation and Africanisation of the game in the late colonial period. In neighbouring Nigeria, Nkrumah was well aware of the use of football by Nnamdi Azikiwe, his fellow African nationalist and later first president of Nigeria, as a vehicle to challenge British colonial rule and embed the notion of an independent Nigeria in the public consciousness. ${ }^{17}$ While the local game in Ghana reflected and at times reinforced what he described as the 'emerging evil' of regional selfinterest, Nkrumah quickly identified in football, a resource that could help to build populist approval for the political agenda of his Convention People's Party (CPP) and generate support for his political campaign for independence and his unitarist vision for Ghana. ${ }^{18}$

As independence neared, he positioned himself more closely to the game and when it became clear that decolonisation was imminent, Nkrumah assumed much more direct responsibility for the management of football. This ensured that the game featured 
prominently in his aspirations to replace regional political chauvinism with a unifying sense of Ghanaianness and in his efforts to build wider pan-African solidarities. Thus, football was placed centre stage in the country's independence celebrations, regional governing bodies were replaced with a single Ghanaian Amateur Football Association (GAFA) and a new national league, comprised of two teams from each of the four major municipalities was established. ${ }^{19}$ The strength of Nkrumah's convictions regarding the contribution of football to his Africanist philosophies were such that in 1961 he established a multi-sport club himself, Real Republicans, who were charged with promoting pan-Africanism and 'the new spirit of the African man'. ${ }^{20}$ This overt politicisation of the game was visibly etched into the football team's shirts through the inscription of the initials 'OOC', which was shorthand for 'Osagyefo's Own Club', a reference to the appellation frequently applied to Nkrumah which roughly translated as 'the victor in war' or 'redeemer'.

Beyond the local scene, Ghana joined CAF and FIFA in 1957 and 1958 respectively and under the stewardship of Ohene Djan, the newly installed chairman of the GAFA and later first Director of Sports, international fixtures were quickly sought out. Reflecting Nkrumah's pan-African agenda, these matches featured games against other newly independent African nations. The rationale behind this and his wider political agenda for sports was spelt out by Nkrumah in 1960;

Not only can sports contribute towards the development of unity and understanding between the regions of Ghana, they have another even more important role to play in present day Africa. Through international competition with other African states, sports can provide that necessary basis of mutual understanding which can so greatly assist the realisation of our ideal of African unity. ${ }^{21}$

In a move designed to further foster African brotherhood through football, the 'Kwame Nkrumah Gold Cup' was initiated in 1960 with the first edition featuring Nigeria, Sierra Leone and, most significantly, Portuguese Guinea, then under Portuguese rule. With the 'Black Stars' increasingly cast in an ambassadorial role, exhibition games to celebrate the 
independence of Kenya and Zambia followed as did matches in the Soviet Union, Germany, Austria, England, Spain and Italy which were organised to challenge prejudices about Africans in Europe. ${ }^{22}$ The biennial African Cup of Nations, inaugurated in 1957 soon became a focal point for the Ghanaian state's efforts to showcase itself internationally, not least when it hosted the tournament in 1963. Spurred on by Nkrumah's personal investment and interest, the hosts secured their first continental crown. In the following year, Ghana qualified for the Olympic football tournament and finished top of their group before losing in the quarterfinals.

While these successes were most welcome, the Ghanaian government had loftier ambitions for the Black Stars and it identified the World Cup as the platform towards which the national team should be aspiring. Indeed, in launching a three year 'soccer development plan' in 1960, Kojo Botsio, then chairman of the GAFA and Minister of Foreign Affairs declared 'we are determined to be world soccer champions one day'. ${ }^{23}$ Three years later Botsio repeated this conviction, suggesting that the progress of African national teams was compelling their Latin American and European counterparts 'to acknowledge the fact that the glory of African soccer is glittering the horizon' ${ }^{24}$ Regardless of this rhetoric, there were few signs that FIFA was willing to translate this acknowledgement into access to the World Cup tournament. In this context, opportunities for Ghana, or other African nations to play on the game's premier international stage and accrue the visibility and prestige that this would furnish remained extremely limited. Reflecting the political climate of the time, emboldened by decolonisation and in keeping with Nkrumah's aspirations to use football to contribute to unity at home and promote his cherished pan-African principles, the response to this state of affairs came in the form of a continent wide boycott of the 1966 competition. 


\section{African Boycott and FIFA's Response}

When FIFA revealed its intention not to allocate a guaranteed qualifying position to either Africa or Asia in January 1964, Ohene Djan, who had just been appointed to FIFA's Executive Committee for a two-year term sent a telegram to FIFA's Executive where he articulated his and indeed, CAF's view;

Registering strong objection to unfair World Cup arrangement for Afro-Asian countries STOP Afro-Asian countries struggling through painful expensive qualifying series for ultimate one finalist representation is pathetic and unsound STOP At the worst, Africa should have one finalist STOP Urgent reconsider. $^{25}$

This initial response was followed up with a more detailed argument, prepared with his Ethiopian colleague Ydnekatchew Tessema, a founding member and later president of CAF, which invoked the principles of 'fair play' and 'equity' in their request for one place at the finals. CAF also warned of the likelihood that the African associations would not take part in the qualifying rounds given that the costs associated with organising a play-off between the winners of the African group and their counterparts from Asia and Oceania were onerously and prohibitively expensive. ${ }^{26}$

While the logic of CAF's argument did gain some traction among FIFA's leadership, ${ }^{27}$ the absence of substantive change led to Djan, doubtless prompted by Nkrumah, tabling the idea of withdrawing from the qualifying rounds of the finals to CAF's Executive Committee meeting in Cairo in July 1964. The response was unanimous and charged with 'making the World Championship a real world manifestation far from any exclusivism', CAF informed FIFA of the intention of all African national associations to withdraw from World Cup qualifying. ${ }^{28}$ Djan who was instrumental in working out the finer details of the boycott strategy, ${ }^{29}$ articulated the rationale behind the boycott by invoking Nkrumah's philosophy around the place of Africans in the post-colonial world; 'We are not asking this as beggars. 
We are putting forward just and moderate demands, taking account of the huge progress made in our football'. ${ }^{30}$ Galvanised by these sentiments, the Asian football confederation whose members were also denied realistic opportunities to qualify for the tournament soon followed Africa's lead, arguing that 'as a World Cup, the competition should represent the world and not just Europe and South America' 31

Given its reluctance to countenance the opening up of its showcase competition in ways that would align with its self-professed internationalist vision for the game, FIFA's decision to impose a fine of 5000 Swiss Francs in July 1965 on each of the national associations that had withdrawn from the competition was hardly surprising. This action not only placed a considerable financial burden on individual national football federations but also increased the antipathy of CAF's constituents towards the world body. A reduction of the fine to 1000 Swiss Francs following the intervention of CAF, did little to abate the African nations' enmity and they clamoured to publicly criticise FIFA's position. For example, Mourad Fahmy, CAF's General Secretary wrote to his counterpart in FIFA decrying what he called the 'absurd' allocation of one guaranteed berth for the World Cup finals to three continents comprising almost half of the world's national Football Associations'. ${ }^{32}$ Ydnekatchew Tessema added to the criticism, arguing that;

FIFA has adopted a relentless attitude against the African Associations and its decisions resemble methods of intimidation and repression designed to discourage any further impulses of a similar nature. In our opinion, the African National Associations which, in spite of the flagrant injustice that drove them to abandon the World Cup series, submitted sportingly to the regulations in force, so as to consolidate the moral authority of the FIFA, really deserved a gesture of respect rather than a fine. ${ }^{33}$

The tenor of this discourse clearly reflected Nkrumah's wider pan-African view that acting in unison, African nations were stronger politically. Indeed, according to the veteran Ghanaian journalist, Ebo Quansah, the unity shown by CAF 'shook the very foundations of 
FIFA' and led directly to its decision, two years later, to grant the continent its own qualifying berth for the 1970 tournament. ${ }^{34}$ Somewhat ironically, Nkrumah was not in a position to continue to champion football or support the Black Stars pursuit of this berth. He had been ousted as president of Ghana in a military coup d'etat in February 1966 and with the removal of Djan from his position at the Ghanaian Sport Directorate in December, the two driving forces behind the boycott were no longer able to influence what became growing calls among African football federations for even greater representation at the World Cup. This is not to suggest that the consequences of the boycott were limited to the enhanced allocation of places for Africa and Asia at the 1970 World Cup. As the remainder of this article argues, the broad agenda that underpinned this strategy continued to percolate through FIFA's political history. More specifically, it opened up space within the world body for the emergence of a patronage based form of governance that precipitated what was described as FIFA's 'crisis' in 2015.

\section{Transforming the FIFA's Governance}

While a guaranteed place for Africa at the 1970 World Cup was symbolically important, in quantitative terms, it did not significantly address the continental imbalances inherent in the world game. With Sir Stanley Rous at the helm of the world body, radical change was unlikely. While Rous had demonstrated modernist, progressive flourishes during his thirteen year tenure as FIFA president between 1961 and 1974, he was a firm believer that UEFA should maintain control over the game's international development and he had adopted a paternalistic attitude to African football. For example, early in his presidency, he expressed concerns that the established European football nations 'should have no more than equal

voting rights with any of the newly created countries of Africa and Asia' ${ }^{35}$ Similar views 
were apparent in an interview that he conducted just prior to his death in 1986, when he described the initiation of football development programmes in Africa as part of FIFA's 'general missionary work'. ${ }^{36}$ Furthermore, his support for the all-white Football Association of South Africa in the lead up to and long after their suspension from FIFA in 1964 not only ran counter to the pan-African sensibilities of $\mathrm{CAF}$ and irked their member federations but also demonstrated an inability to navigate the political realities of a volatile post-colonial world. ${ }^{37}$ Nonetheless, the experience and outcome of the boycott had emboldened CAF to continue to pursue their ambitions within FIFA and they soon recognised that fulfilment of their aspirations required a change in leadership at the head of the organisation. Galvanised by the 1966 boycott, and its outcome, CAF identified in the candidacy of the Brazilian business magnate, João Havelange, the strategy most likely to deliver this.

The story of Havelange's rise to power at FIFA's Frankfurt congress in 1974 is welltrodden and does not require revisiting for this article. ${ }^{38}$ What is relevant for the discussion here is the fact that from an African perspective, this momentous event in FIFA's and indeed, World Cup history was not only rooted in and driven by the same political sentiment that gave rise to the boycott but it also reflected the growing confidence of African nations to shed the strictures of European colonialism and assert themselves in the postcolonial world. As a shrewd observer of the political climate in world football at the time, Havelange made it clear during his three year canvassing campaign and through his election manifesto that he intended to set FIFA on a more internationalist path, one that would bring increased opportunities for its newer members. In return, they were happy to reciprocate with their votes. These votes were clearly the key in a result which signalled an unparalleled transformation in the affairs of FIFA as the balance of power shifted from the northern to the southern hemisphere. Rhamadan Ali, the former Tanzanian international player and eminent journalist, summarises this view well; 
The balance of power was held by the AFC [CAF] bloc (with 37 votes). In the vote it became clear that the battle was between the old guard and the third world with Africa playing a decisive role...By ousting Sir Stanley, Africa and the rest of the third world have struck a resounding blow for a more equitable distribution of sporting power and influence in the world...it [CAF] has brought its influence to bear on a number of issues and has succeeded in breaking Europe's monopoly of world football. ${ }^{39}$

With the FIFA Presidency safely secured for a four-year period, Havelange immediately set about formulating the strategy that would enable him to fulfil the expensive promises he had made to the third world as part of his election strategy. To do so, the Brazilian needed to procure the necessary financial backing and with his marketing partner, Patrick Nally, he was able to broker major sponsorship deals with Adidas and Coca-Cola followed by the signing of lucrative, and what we now know to be ethically problematic, partnerships with transnational media partners, not least International Sport and Leisure (ISL). ${ }^{40}$ In a relatively short period, FIFA went from being an organisation with modest financial means to one awash with capital. Indeed, in noting his accomplishments as his 24 year tenure in office came to a conclusion, Havelange referenced the fact that FIFA's financial reserves had been negligible when he came to power and exceeded $\$ 4$ billion when he left. ${ }^{41}$ Once the Brazilian had successfully married the interests of FIFA, Adidas and Coca-Cola, he embarked on the practical realisation of his manifesto. A range of development programmes were established in Africa and Asia, two new world youth tournaments were inaugurated and hosted regularly by third world countries and steps were taken to increase the number of African and Asian nations taking part in the World Cup Finals. These developments on the field of play were matched by a gradual democratisation in FIFA's committee structures which allowed Africa an enhanced say in the governance of world football.

Whether the policy shift that Havelange instituted and his advocacy of a more globalist vision for FIFA was motivated by a genuine desire to enfranchise the world game's 
developing regions or was underpinned by an aspiration for power and the status and material trappings that came with the most senior administrative position in world football has long been debated and there is a consensus that the latter should read as the more accurate epitaph for the Brazilian. ${ }^{42}$ What is beyond question is the fact that his ascension to the presidency with the considerable assistance of African votes heralded in a period of radical transformation in how and for whom FIFA operated. Of course, as we now know, this transformation has also brought with it considerable issues in terms of governance. In particular, it introduced a set of dynamics that shaped FIFA politics for decades to come, positioned Africa as a key constituency around which these dynamics cohered and entrenched a patron-client based form of governance at the heart of the organisation that was frequently characterised by corruption and unethical financial practices. These processes coalesced and became particularly visible during a number of election campaigns for the FIFA Presidency. This was perhaps most apparent when the Swede, Lennart Johansson, then head of the European football confederation (UEFA), took the decision in 2015 to run against Havelange in the 1998 election. A brief overview of this campaign is useful by way of illustration.

When he announced his candidature to run against Havelange in 1995, Johansson quickly recognised the importance of brokering better relations with FIFA's sizeable African constituency if his campaign was to be successful. His approach in this regard was embodied in a set of proposals aimed at revolutionising the organisational, political and financial base of world football and radically altering UEFA's approach to other continental confederations. Indeed, in articulating the rhetoric behind the initiative, UEFA suggested that it now 'recognised the progress of all the continental confederations and considered them as equal partners, who should be appropriately involved in FIFA matters' ${ }^{43}$ The central objective of the proposals was to incorporate and involve the confederations, in a more pivotal manner, in the administration of international football. For example, Vision I proposed a system of 
rotation around the confederations for the hosting of World Cup finals as well as the FIFA Presidency whilst Vision II was directed at ensuring that national associations would, for the first time, have a direct share of revenues generated by the World Cup Finals. ${ }^{44}$ Alongside the Vision proposals, Johansson also put in place an accord between CAF and UEFA, the Meridian Project, which provided financial, technical and technological aid to selected African football associations. ${ }^{45}$

While these efforts in brokering this new relationship with African football were reflective of the Swedish social democratic, welfarist and internationalist values that Johansson had been steeped in as part of his upbringing, they were also rooted in political expediency and a belated recognition from UEFA that winning back the presidency required a transformation in the sort of attitudes that had led to the African boycott of the 1966 World Cup and Havelange's subsequent election in $1974 .{ }^{46}$ Havelange's decision not to continue with his candidacy only a matter of months before the vote, following a series of political mishaps and miscalculations, appeared to give Johansson a clear run at the presidency. However, three months prior to the election, Sepp Blatter, FIFA's former General Secretary and long-time Havelange confidant, entered the election fray. Despite the fact that Blatter had yet to formally announce his candidature, Havelange began to canvass vigorously on behalf of his close ally. In particular, the Brazilian focused on FIFA's developing constituencies and his forceful and politically shrewd electioneering in Africa presented major problems for Johansson's campaign strategy and his alliance with CAF. The difficulty with attempting to procure unanimous African support was, of course, that any candidate backed by the outgoing President would appeal strongly to the many African national associations which had benefited from the Brazilian's development initiatives and patronage during his twentyfour years in office. 
Alongside the Brazilian's lobbying efforts, Blatter presented himself as an advocate of African football and his increasingly vociferous support of South Africa's bid to host the 2006 World Cup was crucial in this respect. Significantly, Blatter's support for Africa in the build up to the Presidential poll went beyond political rhetoric. Almost directly paralleling Havelange's canvassing efforts in Africa prior to securing the presidency in 1974, he concentrated his electioneering in this constituency. Two weeks before the election, a clearer picture of likely voting trends had emerged and this indicated that the candidate who could curry most favour with the forty-four African nations eligible to participate in the proceedings of the Paris Congress would be the new FIFA President. ${ }^{47}$ As events transpired, a late change of allegiance within the African bloc, precipitated by offers of financial assistance from Blatter, ultimately gifted the Swiss the FIFA presidency. ${ }^{48}$ As was the case in 1974 , this election, and Africa's importance in determining the outcome, further entrenched the patronclient bonds that had come to characterise and determine FIFA's governance and policy direction. Furthermore, while it was never established whether Blatter had acted unethically in offering financial support to voting associations prior to the election, the US Department of Justice (DoJ) indictment of a number of high ranking FIFA officials in May 2015, tends to support the view that the outcome of the election was underpinned by the corrupt practices and malign culture that have long festered at the centre of the world body. ${ }^{49}$

\section{Conclusion}

Irrespective of one's view of the individuals who led FIFA's post-1974 transformation, the world body became much more outward looking and football's emerging regions were better supported. While it can be argued that the support of a Brazilian for these regions reflected Latin America's leadership of the wider non-aligned movement that had acquired particular 
prominence by the mid-1970s, the alliances that were nurtured in the lead up to the election and beyond were also rooted in political expediency and underpinned by Havelange's personal ambitions. ${ }^{50}$ The significance of this is that it opened up space for the emergence of an explicitly patronage based form of governance within FIFA. As this article has shown, the African boycott of the 1966 World Cup was significant in this regard because it had clearly highlighted to Havelange the political value of both deploying the rhetoric of enfranchisement and acting on it as a way of securing and retaining the presidency. Sepp Blatter's presidency further entrenched these patron-client bonds and ensured that FIFA's key policy decisions reflected the aspirations of FIFA's emerging regions. However, rather than be celebrated as a laudable outworking of what were justifiable and entirely appropriate demands around the 1966 World Cup, this patron-client form of governance frequently lapsed into cronyism, nepotism and corruption, processes that ultimately led to FIFA's 'crisis' in 2015.

In launching its post 'crisis' reforms in October 2016, the new FIFA President, Gianni Infantino, who had been elected nine months previously, set out a 'roadmap', the 'FIFA 2.0 Vision for the Future', that he claimed would make the world body a more transparent, open and democratic organisation. At the same time, he pledged to introduce new governance arrangements and oversight mechanisms that would tackle the financial corruption that the DoJ and Federal Bureau of Investigation (FBI) indictment had revealed to be endemic and institutionalised within the world body. ${ }^{51}$ While there are some promising signs as this reform process, overseen by the DoJ and FBI, has taken hold and as FIFA has begun to stride out on this 'new' policy and governance direction, only time will reveal whether and how the world body will differ from its pre-2015 incarnation. What is clear however, is that the events and sentiments that led to the African boycott of the 1966 World Cup still echo in FIFA's 
corridors of power, and more specifically, continue to impact the world game's showcase event.

As noted earlier, the most immediate ramification of the boycott was the granting of automatic qualifying berths for the 1970 tournament to African and Asia. By 1982, the competition had been enlarged to 24 teams and it was increased in size to 32 from 1998 onwards. These decisions were partly motivated by a desire to better accommodate previously disenfranchised constituencies at the World Cup and enabled Havelange not only to retain his seat at the helm of world football but to decisively influence Sepp Blatter's succession at the Paris Congress in 1998. For all its emphasis on reform, the 'FIFA 2.0' vision can also be viewed in policy terms as contiguous with the past and there are similarities with the expansionist and democratising rhetoric employed by Havelange and Infantino. Infantino's role in shaping the world body's 'new' vision may reflect nothing other than a desire to expand the reach (and finances) of the organisation that he leads. However, FIFA's post-Rous history suggests that an awareness of how such a philosophy might resonate with important voting blocs is never too far away from the thoughts of those with ambitions in sports governance. Indeed, the Infantino led decision to enlarge the World Cup to 48 teams from 2026 can be interpreted as being underscored by the same realpolitik that marked the previous expansion of the competition. In justifying his proposal, and no doubt well aware of how his justification would play out in FIFA's African constituency, Infantino unwittingly harked back to the same principles that underpinned the 1966 boycott;

Football is more than just Europe and South America, football is global...Football promotion, in many parts of the world where today they have no chance to play [at the World Cup] was at the top of our thoughts. ${ }^{52}$

The fact that a European FIFA president, some fifty years after the boycott of the 1966 finals, invoked the same sort of rhetoric employed by Nkrumah, Djan, Tessema and 
others is perhaps the clearest indication of the enduring legacy of this momentous event in football history.

\section{Notes}

${ }^{1}$ CAF, Circular Letter, 21 August. 1964.

2 Darby, Africa, FIFA and Football.

${ }^{3}$ Sugden and Tomlinson, FIFA and the Contest for the World Game.

${ }^{4}$ Alegi, African Soccerscapes; Boer, 'Football, Mobilisation and Protest'; Darby, 'Let Us Rally Around the Flag'; Darby, 'Football and Identity Politics in Ghana; Fair, 'Kickin' It'; Fates, 'Football in Algeria'; Hawkey, Feet of the Chameleon; Lema, 'Sport in Zaire'; Martin, 'Colonialism, Youth and Football'; Ndee, 'Sport, Culture and Society'; Rosbook-Thompson and Armstrong, 'Fields and Visions'; Versi, Football in Africa ${ }^{5}$ Stuart, 'Lion's Stir', 34.

${ }^{6}$ Alegi, African Soccerscapes.

${ }^{7}$ Darby, Africa, FIFA and Football.

${ }^{8}$ Rofe and Tomlinson, 'The untold story of FIFA's diplomacy'.

${ }^{9}$ Darby, 'Africa and the World Cup'.

${ }^{10}$ G. Weiderkehr, cited in Official Bulletin of UEFA, 14. Weiderkehr's successor, Artemio Franchi, maintained his predecessors stance well into the 1970s, articulating his consternation that FIFA's statutes did 'nothing to stop these emerging football countries from joining the enlarged FIFA family', and describing this state of affairs as 'the uncomfortable truth' (author's italics). Franchi, 'Europe and World Football', 21.

${ }^{11}$ Bangerter, 'UEFA Past and Present'.

${ }^{12}$ UEFA, Minutes of the Executive Committee Meeting, 13 February 1964.

${ }^{13}$ Spain defeated Morocco to leave Africa without a representative at the 1962 World Cup.

${ }^{14}$ Olaosebikan, 'Kwame Nkrumah'.

${ }^{15}$ Nkrumah, 'Africa Must Unite'.

${ }^{16}$ Birmingham, 'Kwame Nkrumah'.

${ }^{17}$ Boer, 'Football, mobilization and protest'.

${ }^{18}$ Darby, 'Let Us Rally Around the Flag'; Birmingham, Kwame Nkrumah.

${ }^{19}$ Kwateng, Asante Kotoko Football Club.

${ }^{20}$ Quansah, 'The Fall of a Soccer Empire',37.

${ }^{21}$ Obeng, Selected Speeches of Kwame Nkrumah, 29-30.

${ }^{22}$ Goldblatt, The Ball is Round; Versi, Football in Africa; Obeng, 'The Sporting Youth'.

${ }^{23}$ Evening News, 4 April 1960.

${ }^{24}$ Cited in The Ghanaian Times, 25 November 1963.

${ }^{25}$ Cited in BBC News, 'How Africa Boycotted the 1966 World Cup'. 11 July 2016.

http://www.bbc.co.uk/news/world-africa-36763036 accessed 04 May 2018.

${ }^{26}$ Ibid.

${ }^{27}$ Rofe and Tomlinson, 'The untold story'.

${ }^{28}$ CAF, Circular Letter, 21 August 1964.

${ }^{29}$ FIFA Minutes of the XXXIVth Ordinary Congress, Tokyo, 8 October, 1964.

${ }^{30}$ Djan cited in Katimia, 'The Fight For Recognition', 54.

${ }^{31}$ Oliver, World Soccer, 24.

${ }^{32}$ Fahmy, Personal communication, 16 August 1965.

${ }^{33}$ Cited in Ibid.

${ }^{34}$ Quansah, 'The cup to surpass', 27; Rofe and Tomlinson, 'The untold story'.

${ }^{35}$ UEFA, Official Bulletin, April 1961.

${ }^{36}$ Goldman, 'My life and times in world football, 12.

${ }^{37}$ Darby, 'Stanley Rous's 'Own Goal'.

${ }^{38}$ Sugden and Tomlinson, FIFA and the Contest for World Football; Darby, Africa, Football and FIFA; Darby, 'Stanley Rous's 'Own Goal'; Darby, 'Africa, the FIFA Presidency; Tomlinson, 'FIFA and the Men Who Made It'.

${ }^{39} \mathrm{Ali}$, In the Big League, 10. 
${ }^{40}$ Conn, The Fall of the House of FIFA; Jennings, Foul!; Sugden and Tomlinson, Football, Corruption and Lies; Yallop, How They Stole the Game.

${ }^{41}$ Tomlinson, 'FIFA and the Men Who Made It'.

${ }^{42}$ Conn, The Fall of the House of FIFA; Jennings, Foul!; Sugden and Tomlinson, Football, Corruption and Lies; Yallop, How They Stole the Game.

${ }^{43}$ UEFA, Report of the General Secretary, 33.

${ }^{44}$ Ibid.

${ }^{45}$ Fahmy, 'The UEFA/CAF Co-operation'.

${ }^{46}$ Bairner and Darby, 'The Swedish Model and International Sport'.

${ }^{47}$ Collett, 'FIFA Presidential Election'.

${ }^{48}$ Prior to the election, Blatter wrote to every FIFA affiliated association offering them a down payment of $\$ 50,000$ on the $\$ 250,000$ annual subsidy that they were to receive from FIFA as part of their share of the revenue from the television and marketing rights of the 1998 World Cup. Africa was clearly to the forefront of Blatter's mind when the offer was made. Yallop, How FIFA Stole the Game.

${ }^{49}$ Bayle, and Rayner, 'Sociology of a Scandal'.

${ }^{50}$ Darby, Africa, Football and FIFA.

${ }^{51}$ FIFA.com. 'FIFA President Infantino unveils "FIFA 2.0: The Vision for the Future". https://www.fifa.com/about-fifa/news/y=2016/m=10/news=fifa-president-infantino-unveils-fifa-2-0-the-visionfor-the-future-2843428.html. Accessed on 20 June 2018.

${ }^{52}$ Cited in BBC Sport. 'World Cup: Fifa to expand competition to 48 teams after vote', 10 January 2017. https://www.bbc.co.uk/sport/football/38565246

\section{References}

Alegi, P. African Soccerscapes: How a Continent Changed the World's Game. London. C. Hurst and Co, 2010.

Ali, R. In the Big League: The Rise of African Football. London: Afropress Ltd, 1984.

Bairner, A. and Darby, P. 'The Swedish Model and International Sport: Lennart Johansson and the Governance of World Football'. International Review for the Sociology of Sport, 36, 3 (2001): 337-359.

Bangerter, H. 'UEFA Past and Present', In 25 Years of UEFA, ed. U. R. Rothenbuhler, 42-44. Berne: UEFA Publications, 1979.

Bayle, E. and Rayner, H. 'Sociology of a scandal: the emergence of "FIFAgate". Soccer and Society. 19, 4 (2018): 593-611.

BBC News, 'How Africa Boycotted the 1966 World Cup'. 11 July 2016. http://www.bbc.co.uk/news/world-africa-36763036 (accessed May 4, 2018).

BBC Sport. 'World Cup: Fifa to expand competition to 48 teams after vote', 10 January 2017. https://www.bbc.co.uk/sport/football/38565246 (accessed, 12 January, 2017).

Birmingham, D. Kwame Nkrumah: The Father of African Nationalism. Athens: Ohio University Press, 1998.

Boer, W. 'Football, Mobilisation and Protest: Nmandi Azikiwe and the Goodwill Tours of World War II'. Lagos Historical Review, 6 (2006): 39-61. 
Collett, M. 'FIFA Presidential Election: Likely Voting Tends'. Reuters, 6 June 1998.

Confédération Africaine de Football, Circular Letter to FIFA from the CAF Executive Committee, 21 August. 1964.

Conn, D. The Fall of the House of FIFA. London: Yellow Jersey Press, 2018.

Darby, P. Africa, Football and FIFA: Politics, Colonialism and Resistance. London: Frank Cass, 2002.

Darby, P. 'Africa, the FIFA Presidency and the Governance of World Football: 1974, 1998 and 2002'. Africa Today, 50, 1 (2003): 3-24.

Darby, P., 'Africa and the World Cup: Politics, Eurocentrism and Resistance', International Journal of the History of Sport, 22, 5 (2005): 883-905.

Darby, P. 'Stanley Rous's 'Own Goal': Football Politics, South Africa and the FIFA Presidency (1974)'.Soccer and Society, 9, 2 (2008): 259-272.

Darby, P. "“Let Us Rally Around the Flag": Football, Nation-Building and Pan-Africanism in Kwame Nkrumah's Ghana, Journal of African History, 54, 2 (2013): 221-246.

Darby, P. 'Football and Identity Politics in Ghana', In Routledge Handbook of Sport and Politics, eds. A. Bairner, Kelly, J and Lee, J. W., 137-149. New York and London: Routledge, 2016.

Evening News, 4 April 1960.

Fahmy, M. Personal communication to Dr Helmut Kaeser. 16 August 1965.

Fahmy, M. 'The UEFA/CAF Co-operation'. In Report of the General Secretary for 1995-97, CAF, 4-5. Cairo: CAF Publications, 1997.

Fair, L. 'Kickin' It: Leisure, Politics and Football in Colonial Zanzibar, 1900s-1950s'. Africa, 67: 2 (1997): 224-251.

Fates, Y. 'Football in Algeria: Between Violence and Politics'. In Football in Africa:

Conflict, conciliation and Community, eds. G. Armstrong and R. Giulianotti, 41-58. London: Palgrave Macmillan.

FIFA. Minutes of the XXXIVth Ordinary Congress. Tokyo, 8 October 1964.

FIFA. Minutes of the XXXVth Ordinary Congress. London, 8 July 1966.

FIFA.com. 'FIFA President Infantino unveils "FIFA 2.0: The Vision for the Future". https://www.fifa.com/about-fifa/news/y=2016/m=10/news=fifa-president-infantino-unveilsfifa-2-0-the-vision-for-the-future-2843428.html (accessed on 20 June 2018). 
Franchi, A. 'Europe and World Football'. Official Bulletin of UEFA, 87 (June 1979): 21. Ghanaian Times, 25 November 1963.

Goldblatt, D. The Ball is Round: A Global History of Football. London: Penguin Books, 2006.

Goldman, K. 'My Life and Times in World Football - Sir Stanley Rous'. World Soccer, (September 1986): 12.

Hawkey, I. Feet of the Chameleon: The Story of African Football. London: Portico, 2009.

Jennings, A. Foul! The Secret world of FIFA: Bribes, Vote Rigging and Ticket Scandals. London: Harper Sport, 2006.

Katimia, M. 'The Fight For Recognition'. African Soccer, 35 (June 1998): 54.

Kwateng, W. Asante Kotoko Football Club: Golden Jubilee, 1935-1985. Kumasi, 1985.

Lema, B. 'Sport in Zaire'. In Sport in Asia and Africa: A Comparative Handbook, ed. E. A. Wagner, 229-247. New York and London: Greenwood Press, 1989.

Martin, P. 'Colonialism, Youth and Football in French Equatorial Africa'. International Journal of the History of Sport, 8, 1 (1991): 56-71.

Ndee, H. 'Sport, Culture and Society from an African Perspective: A Study in Historical Revisionism'. International Journal of the History of Sport, 13: 2 (1996): 192-201.

Nkrumah, K. Africa Must Unite. London: Panaf Books, 1963.

Obeng, K. 'The Sporting Youth Salute the Party', The Ghanaian Times, 13 June 1964.

Obeng, S. Selected Speeches of Kwame Nkrumah, Vol. 1. Accra, 1979.

Olaosebikan, A. J. 'Kwame Nkrumah and the proposed African common government', African Journal of Political Science and International Relations, 5: 4 (2011), 218-228.

Oliver, G. World Soccer: The History of the Game in Over 150 Countries. London: Guinness Publishing, 1992.

Quansah, E. 'The Fall of a Soccer Empire', West Africa - Special Edition (March 1990): 37.

Quansah. E. 'The cup to surpass all cups', Africa Today January/February 1996): 27.

Rofe, S. and Tomlinson, A. 'The untold story of FIFA's diplomacy and the 1966 World Cup: North Korea, Africa and Sir Stanley Rous'. The International History Review, Online First (2019): 1-22. 
Rosbrook-Thompson, J. and Armstrong, G. 'Fields and Visions: The 'African Personality' and Ghanaian Soccer'. Du Bois Review, 7: 2 (2010): 293-314.

Stuart, O. 'The Lions Stir: Football in African Society' In Giving the Game Away: Football, Politics and Culture on Five Continents, ed. S. Wagg, 24-51. Leicester: Leicester University Press, 1995.

Sugden, J. and Tomlinson, A. FIFA and the Contest for World Football: Who Rules the People's Game. Cambridge: Polity Press, 1998.

Sugden, J. and Tomlinson, A. Football, corruption and Lies: Revisiting 'Badfellas', the Book FIFA Tried to Ban. London and New York: Routledge, 2016.

Tomlinson, A. 'FIFA and the Men Who Made It'. Soccer \& Society, 1, 1 (2000): 55-71.

UEFA. Minutes of the Executive Committee Meeting, Frankfurt, 13 February 1964.

UEFA.UEFA Official Bulletin, No.16 (April 1961).

UEFA. Report of the General Secretary for 1994 and 1995. Berne: UEFA Publications, 1995.

Versi, A. Football in Africa. London: Collins, 1986.

Weiderkehr, G. cited in Official Bulletin of UEFA, 23(June 1963): 14.

Yallop, D. How They stole the Game. London: Poetic Publishing, 1999. 